\title{
Performance evaluation of newly developed variable rate sprayer for spray deposition in guava orchard
}

\author{
SACHIN VILAS WANDKAR*, YOGESH CHANDRA BHATT, H. K. JAIN ${ }^{1}$ AND K. G. DHANDE ${ }^{2}$
}

Department of Farm Machinery and Power Engineering, College of Technology and Engineering, Maharana Pratap University of Agriculture and Technology, UDAIPUR (RAJASTHAN) INDIA

${ }^{1}$ Department of Agricultural Statistics and Computer Application, Rajasthan College of Agriculture,Maharana Pratap University of Agriculture and Technology, UDAIPUR (RAJASTHAN) INDIA

${ }^{2}$ Department of Farm Machinery and Power, College of Agricultural Engineering, Dr. Balasaheb Sawant Konkan Krishi Vidyapeeth, DAPOLI (M.S.) INDIA

\section{ARITCLE INFO}

Received : 27.01 .2017

Revised : 11.03 .2017

Accepted : 16.03.2017

\section{KEY WORDS :}

Ultrasonic sensor, Variable rate sprayer, Precision farming,

Orchard sprayer
*Corresponding author:

sachinwandkar85@gmail.com

\begin{abstract}
Application of pesticide inside orchards with conventional sprayers often results in an inefficient application as these are constant rate applicators and also the significant amount of pesticide gets lost in spaces between trees. To reduce the pesticide losses inside orchards, a variable rate sprayer was developed which sprayed only after the occurrence of the tree and according to the size of the tree. The performance of the developed variable rate sprayer was evaluated inside guava trees to quantify the spray deposition at six different plant positions. The sprayer was operated at three forward speeds (2, 3 and $4 \mathrm{~km} / \mathrm{h})$ with four air velocity levels $(20,25,30$ and $35 \mathrm{~m} / \mathrm{s})$ and two different types of nozzles (hollow cone and flat fan nozzle). The observed data was statistically analyzed to study the significance of selected parameters on spray deposition. The spray deposition was found to significantly increase with the increase in air velocity and hollow cone nozzle was able to deposit more amount of spray as compared to flat fan nozzle. There was no significant variation was observed with different forward speeds. The maximum spray was deposited on upper leaf surface at all selected plant position. The uniform spray deposition was observed with the air velocity of $35 \mathrm{~m} / \mathrm{s}$ and hollow cone nozzle. Even though the developed variable rate sprayer varied the discharge of nozzles according to tree size, it was able to deposit the adequate amount of spray at all selected plant positions.

How to view point the article : Wandkar, Sachin Vilas, Bhatt, Yogesh Chandra, Jain, H.K. and Dhande, K.G. (2017). Performance evaluation of newly developed variable rate sprayer for spray deposition in guava orchard. Internat. J. Plant Protec., 10(1) : 96-102, DOI : 10.15740/HAS/ IJPP/10.1/96-102.
\end{abstract}

